\title{
COMMUNITY COOPERATION FOR TOURISM DEVELOPMENT
}

Dace Kaufmane ${ }^{1}$, Dr.oec; Liga Paula², Dr.sc.soc.

1,2Latvia University of Life Sciences and Technologies

\begin{abstract}
Cooperation and research on related issues in the tourism sector is still topical as virtually no new tourism offer is possible without cooperation. This has been confirmed by previous studies. However, in the context of community initiatives, cooperation in tourism has not been analysed very much. The aim of the paper is to analyse community cooperation in rural tourism development on the basis of content analysis of the LEADER projects and previous studies on collaboration. Cooperation is based on the understanding and exchange of information facilitated by existing and new forms of common actions between public and private actors. The results reveal that community cooperation for the development of rural tourism in Latvia can be seen as structural with the Rural Support Service as a central actor, which is responsible for the uniform implementation of the state's and European Union's support policy in Latvia, monitors compliance with agricultural legislation and regulates the conditions of all involved. At regional level, cooperation is coordinated by rural partnerships and governed by their strategies that sets clear objectives for local action in communities.
\end{abstract}

Key words: community, cooperation, LEADER, Local Action Groups, rural tourism.

JEL code: R19, Z32

\section{Introduction}

In market economy, tourism is analysed as both a form of leisure activities and an important sector of national economy. Businesses develop their offer, thus in the context of tourism development the main research object is providers of tourism services in both urban and rural areas. However, many studies have confirmed a need for cooperation in the creation of tourism services. The quality of tourism services depends not only on the innovations created by the entrepreneurs, but also on the environment, and the infrastructure that ensures opportunities to reach desired destinations. There are challenges which tourism business cannot address alone. This is especially crucial in rural areas, therefore in the paper the authors specifically focus on solving rural tourism development issues through the lens of cooperation, which involves local communities as partners. To the great extent, involvement of local communities in rural development in Latvia, similarly to other member states of the European Union, is implemented as a part of the Common Agricultural Policy through the LEADER program and bottom-up approach. In Europe, since the late $20^{\text {th }}$ century, the philosophical basis of rural development policy is developed on an idea of balance between exogenous and endogenous factors, which means that neo-endogenous development schemes include both participatory approach and facilitative role of the state (Shucksmith, 2010). In Latvia, 35 Local Action Groups (LAGs) cover its territory supporting local development through diverse projects and involvement of local communities. Among other projects, great part of local initiatives is related to rural tourism. Therefore, community activities in development of rural tourism can be analysed by reviewing LEADER projects. The aim of the paper is to analyse community cooperation in rural tourism development on the basis of content analysis of the LEADER projects and previous studies. The tasks of the paper are as follows: to describe the nature of communities and the role of the Rural Support Service in local tourism, to reveal conceptual cooperation models of community involvement. Content analysis was used as a research method to reach the aim.

\footnotetext{
1Dace Kaufmane e-mail: Dace.Kaufmane@llu.Iv, +37129904840

${ }^{2}$ Liga Paula e-mail: Liga.Paula@llu.Iv, +371 26321667
} 


\section{Research results and discussion}

Tourists are mainly interested in regions where, in addition to the initial offer, visitors can enjoy an attractiveness of a place and brand-new activities. In order to be sufficiently attractive and, over time, to become a specific tourism product for the region, it should be based on cooperation and evaluation of this cooperation. The unifying element and driving force behind the development of tourism is the institutional and legal framework, enforced by public authorities, which in a sense reflects the social agents involved in the tourism industry and their responsibility in co-operating and generating tourism offerings. Collaboration is important in solving different problems. It is emphasized in the literature that cooperation mainly takes place to solve structural problems, not just occasional situations (Biel A., Snyder M., Tyler T., Vugt M., 2000). However, emphasis is also placed on aspects of cooperation, such as volunteering by stakeholders to share common interests and objectives, visible different problem aspects, action, decision-making, leadership, research and communication through common institutions, laws and regulations (Fyall A., Garrod B., 2005; Kaufmane D., 2011).

Coordination is essential for cooperation and is characterized by different policies, strategies and measures that coordinate the activities of different actors, both public and private, in the tourism industry, although each has its own tasks. A variety of means can be used to achieve cooperation joint venture, tourism councils, foundations, joint institutions, and other forms of cooperation (Briesch R., 2005). Sharing experience and skills and long-term investment projects are key aspects of collaboration and optimization efforts. It is important to note that such cooperation is most effective at the local level, where public and private interests are most directly and directly exposed (Briesch R., 2005; Kaufmane D., 2011).

In rural areas of Latvia, small tourism providers offer services as tourism destinations, but in essence, any business at a tourism destination place does not operate in isolation, because cooperation with other tourism partners depends on the entrepreneur's recognition, which in turn affects turnover. Tourism entrepreneurs form a system of cooperation with specific cooperation partners, each of which has a role to play in developing a tourism product (Kaufmane D., 2011). From 2009 to 2011, the research was carried out in Zemgale region in order to identify cooperation models in rural tourism at micro level, revealing the networks of tourism entrepreneurs (Kaufmane D., 2011). The data showed that the tourism supply creation process is an activity influencing an involvement of new partners in the tourism cooperation system. The collaboration is formed and changed by the purposeful cooperation of the tourism service providers with the partners directly and indirectly involved in tourism. Research on cooperation motives in rural tourism revealed that entrepreneurs, based on subjective but substantiated motives, cooperate with 28 social agents: tourism information centres, industry associations, non-governmental organizations, rural consultancy offices, educational and cultural institutions, museums and collectors, municipalities, advertising agencies, publishers, banks, security companies, insurance companies, companies providing household services, farms, tourism companies, media, craftsmen, souvenir producers, transport companies, catering companies, hotels, rental companies, and Rural Support Service (Kaufmane D., 2011). Most of the agents represent local communities, therefore, the authors of the paper emphasize a need for more detailed research of some cooperation agents in the context of future cooperation. In this case, the authors focus more precisely on the role of the Rural Support Service and local communities in the development of rural tourism. 
Community is a socially constructed concept that has several meanings. Sociologists define a community in three ways: as a social system, as a fixed locality, and as a quality of relationships. This applies both to the area where group members interact and to a set of people that do not represent a single geographic area but are united on the basis of common interest. These types of communities often overlap. A community as a social system meets the needs of its members. Essential features of a community are, for example, common identity, sense of place, human relationships, environment, and culture. Community relationships are based on shared history, values and norms, status and role models, mutual expectations. These elements create a sense of identity that is psychologically and socially significant (Blackshaw T., 2010).

The internal environment of the community determines the capacity of the community to take advantage of different opportunities (Paula L., 2016). What matters is whether the locals themselves can see how they can contribute to the quality of life in the community. In Latvia, rural initiatives are supported by various associations of non-governmental organizations, such as the Civic Alliance, the Latvian Rural Forum, the Community Initiative Fund and others. Municipalities also support local initiatives to the extent possible within the budget. There are LEADER Local Action Groups (rural partnerships) throughout the territory of Latvia, which are active in implementing diverse community projects that are more culturally and socially oriented; however, there is also a tendency to implement initiatives which support local businesses. The Rural Support Service (RSS) is a state direct administration institution, which is responsible for the unified implementation of state's and the European Union's (EU) support policy in Latvia. It supervises compliance with regulatory enactments in the field of agriculture and performs other functions related to implementation of agricultural and rural support policy. Within its competence, the RSS administers state support and the European Union support for rural, agriculture, forestry and fisheries - adopts and evaluates applications for support, decides on granting or refusing to grant funding, decides on the payment or refusal to pay support, and records the paid support and utilization control (Lauku atbalsta dienests).

It is essential for entities to use their strengths and work with others to achieve their goals. Entrepreneurs need to innovate to add value to goods and services they offer. Cooperation between rural tourism service providers emphasizes a new offer as a result of cooperation (Kaufmane D., 2011). RSS is one of the organizations most often contacted by rural tourism businesses for financial support to expand their tourism product. The LEADER approach, which is based on the development of a local development strategy 2015-2020 in the form of projects, has the possibility to attract support from measures co-financed by the European Agricultural Fund for Rural Development (EAFRD) and the European Fisheries Fund (EFF). Central element of local rural environment and its development are people who are the main drivers of development. In order to reduce rural depopulation and the degradation of rural areas, it is important to improve the quality of rural environment so that inhabitants can secure their social and economic activities as close to their place of residence as possible and see themselves in rural areas in the future. To conclude, the LEADER program is an important instrument for the preservation and development of rural areas in order to strengthen community resilience, which is the basis for sustainable development of the area. Content analysis was used in the paper to analyse aspects of community cooperation. Information on partnerships in Latvia and publicly available information on projects implemented since 2009 on the websites of these partnerships has been selected as the subject of the study (Latvijas Lauku Forums). 35 LAGs or partnerships covering the whole territory of Latvia are registered as members of the 
Latvian Rural Forum. The partnership is an open organization and brings together members from a variety of sectors such as municipal representatives, the non-governmental sector, business, and individuals who meet at least once a year. Approved strategies for all partnerships are available on the Rural Support Service website. These documents also include tourism development tasks (Projekti un investicijas). However, development of tourism is not just an activity of one business; it should be understood that the scenery and offerings publicly available in the surrounding area at tourism destinations are important to travellers. Analysing the projects applied and implemented by the communities in Latvia, it was noticed that many of them both improve the quality of life of the local population and have a positive impact on the travellers' rating of the place visited. According to publicly available information on the websites of all partnerships, 405 LEADER projects could be attributed to tourism development in Latvia (both programming periods 2007-2013 and 2014-2020). The most tourism related projects are in the planning regions of Kurzeme and Pieriga (Figure 1), which may be explained by the more active tourism sector in Kurzeme, especially in the coastal areas. The case of Pieriga phenomenon can be at least partially explained by the density of partnerships - there are nine partnerships.

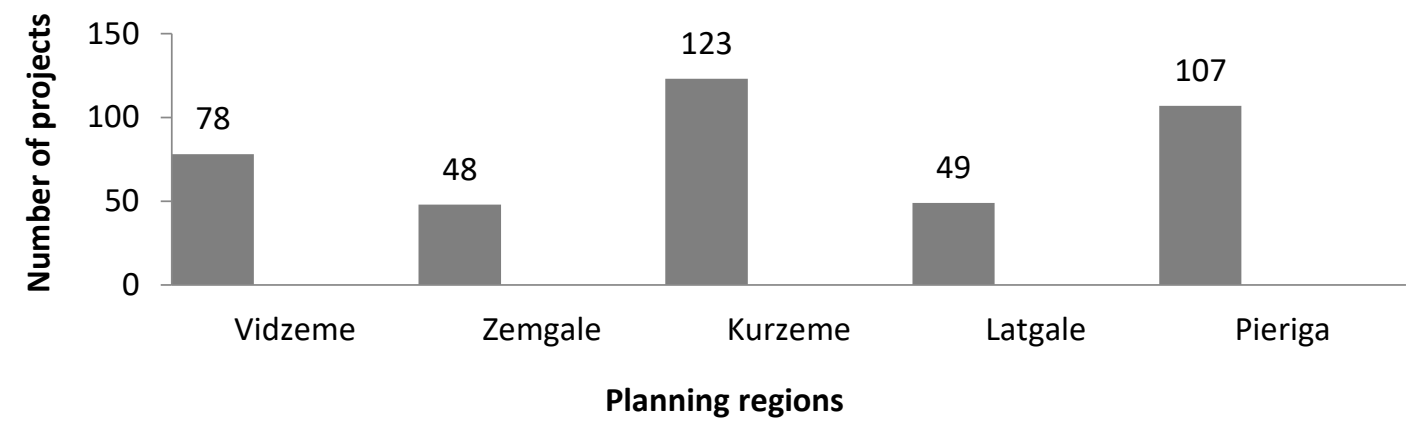

Source: author's calculations based on Latvijas Lauku Forums, Vietejo ricibas grupu (VRG) karte

Fig. 1. Number of LEADER supported projects in Latvia's regions directly and indirectly related to tourism, programming periods 2007-2013 and 2014-2020

The information available on the partnership websites shows that the activities of local communities are related to various project applications: improving tourist accommodations, starting a tourism business, and developing a new product. Projects include activities related to infrastructure improvements and other activities that enhance the attractiveness of the site. Communities are interested in preservation of local historical heritage, creation of exhibitions of collections, in commemoration of important personalities, and preservation of traditional rural landscapes by cleaning up nature objects, parks and bathing areas. Figure 2 presents the main themes of projects.

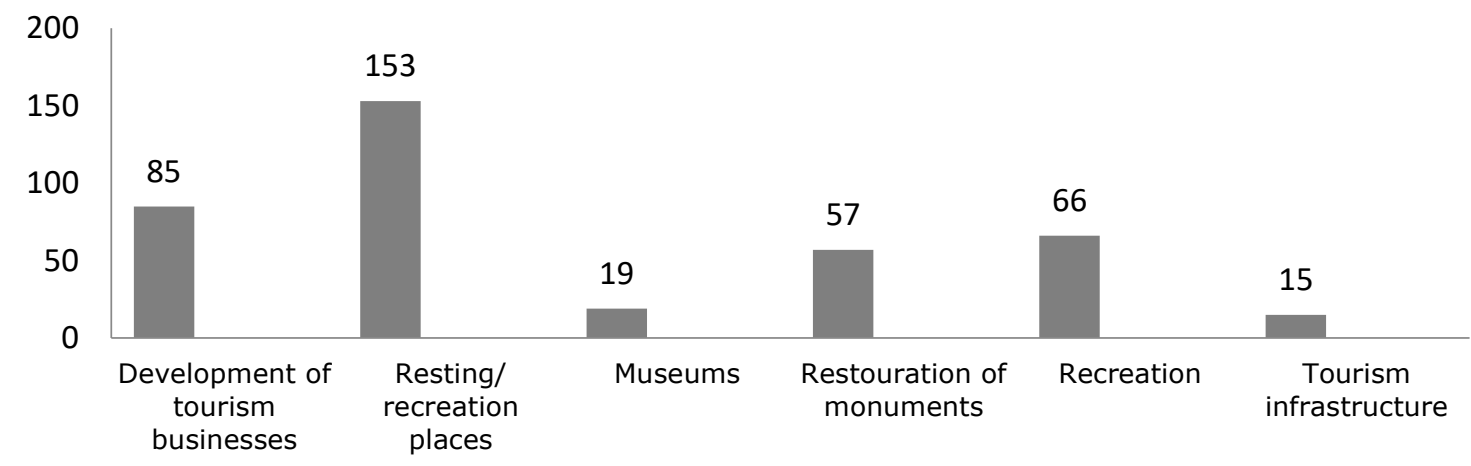

Source: author's calculations

Fig. 2. Number of LEADER supported tourism projects in Latvia by their content since 2009 
The data show that many projects have been implemented specifically for the diversification of tourism services and also for starting new business. These include projects related, for example, to repairs of the guest houses, camping outfitting, purchasing bath equipment, setting up a spa, setting up tour farms, opening cafes and other activities directly related to tourism. In the category of resting/recreation places, the authors included projects for specially designed recreation areas, as well as the improvement of nature trails, access to objects or bathing areas. The tourism industry is also interested in projects that supplement or form a museum foundation. Some examples can be mentioned such as the creation of an exhibit on the cultural heritage of Seda town (Vidzeme region), improvements to the Museum "Pastarins", and synergies between the Livonian and underwater heritage of Kolka. Local communities also work together to preserve the tangible cultural and historical heritage (category restoration of monuments). Small projects related to the maintenance of sacred tourism resources (restouration of churches, mainly in Latgale region), as well as improvement of castles and manor territories, are being implemented, thus making them more attractive to both local communities and visitors. In the category of recreation, projects for custommade objects and offers are included. Examples include the creation of Rope Park in Broceni Mezaparks (Kurzeme region), rope trails in trees in Rezekne municipality, an archery, modernization of the cross-country skiing track at Milzkalns Recreation Complex, and diversification of the services provided by Wakeboarding Park in Marupe (Pieriga region). Projects to improve tourism infrastructure, involve activities directed towards renewal of tourist information signs, information and improved surrounding of facilities, such as reducing anthropogenic pressures and climate change by using environmentally friendly resources and installing alternative energy-powered lanterns. Interesting example is a project "Let the world see us" submitted by the association "Rajumi" (Matkule pagasts), whithin which the Google's free software and Google Earth information system displays digital photographs of objects placed by PANORAMIA, and are linked to the geographic coordinates of the location of the object, thus increasing popularity of natural and cultural sites of Kandava municipality.

Analysis of cooperation in LEADER projects in the context of communities allows to identify two conceptual models of collaboration. The first model, which is between communities, takes place through the preparation and implementation of a particular project (Figure 3).

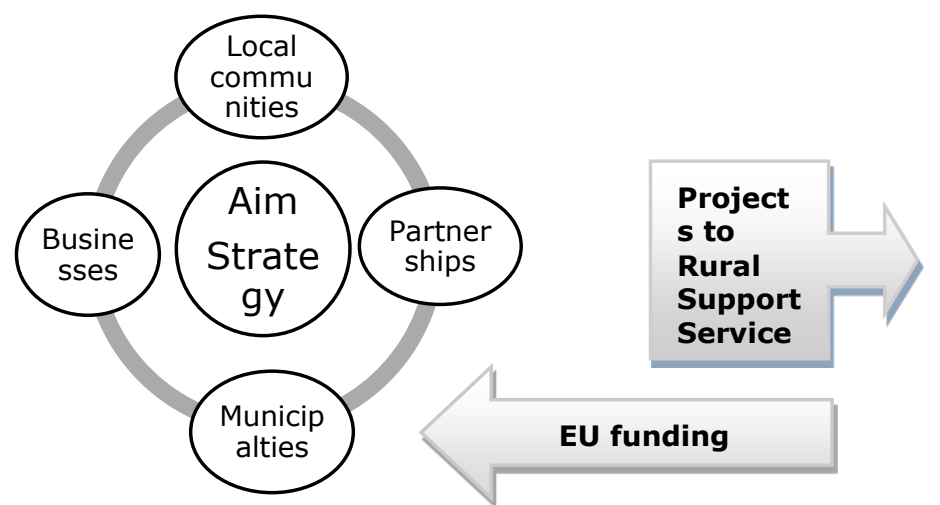

Source: author's construction

\section{Fig. 3. Cooperation agents in preparation and implementation of LEADER projects}

For the development of tourism in rural areas, LEADER projects are submitted by tourism businesses, domestic producers and individuals. Municipalities are also cooperating with the partnerships on projects to improve recreation facilities, improve bathing areas, infrastructure and other conditions. There are also several museums under municipal administration implementing 
LEADER projects, for example, there is a restoration project of $\mathrm{V}$. Pludonis Museum granary in Ceraukste (Zemgale region).

The Law on Local Governments defines the functions which the local government must perform independently (Likums "Par pasvaldibam"). They are linked to the promotion of the socio-economic environment as well as education and culture and the quality of the performance of these functions can also have a positive impact on the development of tourism. A broader spectrum of this collaborative model is the range of local communities. Churches, volunteers, hunters, anglers, sports and various other local initiative groups are involved here. In rural tourism, interaction focuses on cooperation where partners work together to address specific challenges. The networks of rural tourism providers are not static; they are shaped by economic and social rules, opportunities, and new situations. Partnerships in this model can be seen as centres for project synergies that maintain up-to-date strategies and collaborate with the RRS. Thus, the second cooperation model can be identified as collaboration between partnerships. In major projects that could promote the development of tourism in larger areas, partnerships implement common projects. For example, six partnership associations (LAGs) from Pieriga region have developed a joint tourism project offering visitours a tour around Riga city. It was expected that 14 municipalities from Pieriga region (Babite, Olaine, Marupe, Kekava, Baldone, Salaspils, Ikskile, Stopini, Ogre, Ropazi, Garkalne, Adazi, Kegums, and Lielvarde) will be involved in the implementation of the project in order to offer Pieriga region as one united tourism destination thus empowering capacity of tourism businesses.

The results of the community cooperation analysis complement existing studies on cooperation in rural tourism and clarify the role of the RSS in tourism development. Collaboration occurs when goals are unattainable as a result of individual action and require joint action by several partners. Cooperation optimization is based on the understanding and exchange of information facilitated by existing and new forms of common actions between public and private actors (e.g. public-private partnership, public consultations, exchange of experience, development of centres). In the case of rural communities, sectoral policies, such as rural development policy and regional development at national and EU level, are also important, defining and influencing local development priorities and schemes of the external resources available for development.

\section{Conclusions}

1) Community cooperation for the development of rural tourism in Latvia can be seen as structural with the Rural Support Service as a central actor, which is responsible for the uniform implementation of the state's and European Union's support policy in Latvia, monitors compliance with agricultural legislation and regulates the conditions of all involved. At regional level, cooperation is coordinated by rural partnerships and governed by their strategies that sets clear objectives for local action in communities.

2) The Local Action Groups play an important role in conceptualising projects and programs aimed at identifying social and economic needs, some of which are directly and indirectly linked to the development of the tourism industry in rural areas. Community projects are another way in which associations, municipalities and businesses can contribute to improving the quality of life.

3) Projects directly related to tourism development aim to diversify rural tourism services in rural tourism businesses by developing new innovative recreation facilities, increasing the capacity of holiday homes and improving the area's capacity for rural tourism. Creation of new jobs in local areas generates additional farm income while strengthening the local economy. 
4) The main results of community-based cooperation projects from tourism-related projects are improvement of the environment and infrastructure, and the preservation and promotion of the cultural and historical heritage.

\section{Bibliography}

1. Blackshaw, T. (2010). Key Concepts in Community Studies. Los Angeles, London, New Delhi, Singapore, Washington DC: SAGE, p. 232.

2. Biel, A., Snyder, M., Tyler, T., Vugt, M. (Eds.) (2000). Cooperation in Modern Society. Promoting the Welfare of Communities, States and Organizations. London: Routledge, p. 264.

3. Briesch, R. (2005). Eiropas Ekonomikas un socialo lietu komitejas atzinums par Turisma politiku un valsts un privata sektora sadarbibu (Opinion of the European Economic and Social Committee on Tourism policy and public - private partnerships). Eiropas Savienibas Oficialais Vestnesis, C74/02, 7.-14. Ipp.

4. Fyall, A., Garrod, B. (2005). Tourism Marketing. A collaborative Approach. Aspects of Tourism. Channel view publications, p. 383.

5. Kaufmane, D. (2011). Cooperation Systems in Tourism: The Case of Zemgale Region. PhD thesis, Latvia University of Agriculture, Jelgava.

6. Lauku atbalsta dienests. Retrieved: http://www.lad.gov.Iv/lv/par-mums/vispariga-informacija/visparigainformacija/ Access: 15.02.2020.

7. Latvijas Lauku Forums Vietejo ricibas grupu (VRG) karte. Retrieved: http://Ilf.partneribas.Iv/vrg-karte-2 Access: 16.02.2020.

8. Likums "Par pasvaldibam". Retrieved: https://likumi.lv/ta/id/57255-par-pasvaldibam Access: 16.02.2020.

9. Paula, L. (2016). Community Capability for Rural Development in Latvia. Doctoral Thesis. University of Latvia, Faculty of Social Sciences, Department of Sociology.

10. Projekti un investīcijas. LEADER. Apstiprinatas strategijas. Retrieved: http://www.lad.gov.lv/lv/atbalstaveidi/projekti-un-investicijas/leader/apstiprinato-strategiju-saraksts-2/ Access: 16.02.2020.

11. Shucksmith, M. (2010). Disintegrated Rural Development? Neo-endogenous Rural Development, Planning and Place Shaping in Diffused Power Contexts. Sociologia Ruralis, No 50(1), pp. 1-14. 